\title{
A Study of Mercury Pollution in Water, Sediment, and Lais (Kryptopterus) Fish in the Melawi Watershed
}

\author{
Bambang Triswanto, Muhamad Agus Wibowo*, Puji Ardiningsih \\ Postgraduate Program of Mathematics and Natural Sciences Faculty of Tanjungpura University, Pontianak \\ 78124, Indonesia
}

\author{
Article history: \\ Submission May 2020 \\ Revised June 2020 \\ Accepted August 2020 \\ *Corresponding author: \\ E-mail: \\ m.agus.wibowo@ \\ chemistry.untan.ac.id
}

\begin{abstract}
Mercury (Hg) is a heavy metal that is very dangerous and toxic. Melawi River, a river with a length of $471 \mathrm{~m}$, passes through four districts namely Menukung, Ella Hulu, Ella Hilir, and Nanga Pinoh which are the main water transportation routes in Melawi regency. This research was aimed to determine the concentration of mercury in water, sediments and Lais (Kryptopterus) fish of mercury bioconcentration factors, and the safety level of consumption the contaminated Lais (Kryptopterus) fish. The mercury measurement using Atomic Absorption Spectroscopy (AAS) showed that the average concentration of mercury found in the water was $1.80 \times 10^{-4} \mathrm{ppm}$, sediments $1.33 \times 10^{-2} \mathrm{ppm}$, and Lais fish 0.291 ppm. Meanwhile, the average bioconcentration factor (BCF) of mercury in Lais fish was $1.677 \mathrm{ppm}$. The maximum daily consumption of Lais fish that were safe for the community consumption at the Melawi watershed was $0,026 \mathrm{~kg} /$ day for adults and $0.006 \mathrm{~kg} /$ day for the children.
\end{abstract}

Keywords: Mercury, Sediment, Lais (Kryptopterus) Fish, Bioconcentration Factor (BCF), Maximum Daily Consumption

\section{Introduction}

Melawi Regency is a regency located in West Kalimantan Province with abundant natural resources, both renewable and unrenewable. Melawi Regency is traversed by two large rivers namely the Melawi River and the Pinoh River, both of which are commonly used as a means of inter-district water transportation which is very important besides land transportation. Melawi River has a length of $471 \mathrm{~m}$, and passes through four districts namely Menukung, Ella Hulu, Ella Hilir and Nanga Pinoh [1]. Gold is one of the riches of natural resources contained in Melawi Regency so it is not surprising that gold becomes one of the main support of people's lives. Gold miners in Melawi are not only carried out on land, but also in watersheds. Gold mining carried out in the two rivers (the Melawi River and the Pinoh River) is feared to have serious environmental impacts, especially on the issue of water pollution along river basins.
One of the pollutants commonly used by local gold miners is heavy metal in the form of mercury (Hg). Local people who carry out gold mining activities, use mercury to separate gold grains from rocks through the amalgam process [2]. The influence of inorganic chemicals such as $\mathrm{Pb}, \mathrm{Cd}, \mathrm{Hg}$ in high levels can cause changes in water quality so that it cannot be used in accordance with its purpose, besides causing the death of aquatic biota life such as fish and plankton [3, 4]. Lais (Kryptopterus) fish is one of the many species of fish that live in the waters of Borneo including the Melawi River. Lais fish is quite popular among the local people to be processed into a variety of food preparations. However, the potential of Lais fish can turn into a toxic source for humans because of its possibility of being contaminated with mercury due to unlicensed gold mining around its habitat. Therefore, this study aimed to examine the prob- 
Table 1. Coordinate points and observation locations

\begin{tabular}{cccl}
\hline Station & Latitude & Longitude & Location \\
\hline I & $-0^{0} 21^{\prime} 18.38^{\prime \prime}$ & $111^{\circ} 48^{\prime} 49.04^{\prime}$ & The Upper Lengkong Nyadom Village \\
II & $-0^{0} 21^{\prime} 01.06^{\prime \prime}$ & $111^{\circ} 48^{\prime} 02.88^{\prime}$ & Lengkong Nyadom Village \\
III & $-0^{0} 21^{\prime} 00.02^{\prime}$ & $111^{\circ} 46^{\prime} 58.27^{\prime}$ & Tanjung Pauh Village \\
IV & $-0^{0} 19^{\prime} 54.75^{\prime}$ & $111^{\circ} 44^{\prime} 42.96^{\prime}$ & The downstream Tanjung Pauh Village
\end{tabular}

lems related to mercury pollution issue happened in the Melawi watershed. This study examined several problems such as the mercury concentrations in water, sediment and Lais (Kryptopterus) fish, mercury bioconcentration factors found in Lais (Kryptopterus) fish as dominant in the ecosystem, and food safety conditions if the biota is consumed.

\section{Material and Methods Study area}

This research was an observational study with a cross sectional study design. The methods used to sample the river water and Lais fish were Inductively Coupled Plasma (ICP), and as for sediments, it used Cold Vapor-Atomic Absorption Spectrophotometry (CV-AAS). The laboratory testing was conducted at the Jakarta Health Laboratory Center and the Sucofindo Laboratory Cibitung. The study was conducted in January to April 2018.

\section{The Sampling-station determination}

The determination of sampling locations for the study of water and sediment quality was carried out with two variations of water discharge. Water and sediment samples taken in this study had several characteristics so that they were considered qualified to be taken as representatives of the population.

As for river water sampling, the determination of sampling locations was carried out at four locations with different criteria: the location that have never been or are slightly polluted which is located at the Upper Lengkong Nyadom Village (ST I), the location where the water was already polluted at Lengkong Nyadom Village (ST II) and Tanjung Pauh Village (ST III), and the location where is being the water sources utilized by the local people at the Lower Tanjung Pauh Village (ST IV) [4] (Table 1). The observation station was determined by purposive sampling.

\section{Water sampling technique}

Water sampling techniques referred to Indonesian National Standard (SNI): SNI 03-7016 -2004 on procedures for sampling in the context of monitoring water quality in a river drainage area, and SNI 6989.57: 2008 concerning water and wastewater section 57: methods for sampling surface water.

\section{Sediment Sampling Technique}

Sediment sampling was carried out according to the instructions of the Japan Public Health Association (JPHA) [5].

\section{Lais Fish Sampling Technique}

The observation station is determined by purposive sampling based on the characteristics of the surrounding environment, namely the area without and with gold mining activities. The size of Lais fish used as a sample is one that weighs $1-1.5 \mathrm{~kg}$.

\section{Mercury Bioconcentration Factor Analysis Techniques}

Bioconcentration factor (BCF) is the tendency of a chemical to be absorbed by aquatic organisms. $\mathrm{BCF}$ is the ratio between the concentration of chemicals in aquatic organisms and the concentration of chemicals in water [6].

$$
\mathrm{BCF}=\mathrm{C} \text { org } / \mathrm{C}
$$

where:

$\mathrm{C}$ org : concentration of heavy metals in organisms ( $\mathrm{mg} / \mathrm{kg}$ or $\mathrm{ppm})$

C : concentration of heavy metals in water (ppm)

\section{Safety analysis techniques consumption of con- taminated Lais fish}

The security equation for fishery product consumption and daily mercury exposure is referred to as the Guidance for Assessing Chemical Contaminant Data for Use in Fish Advisories [7] as follows:

$$
\mathrm{CRlim}=(\mathrm{Rfd} \times \mathrm{BW}) / \mathrm{Cm}
$$


Information:

CRlim : Maximum allowable consumption (ppm / kg / day)

$\mathrm{Cm} \quad$ : Mercury Concentration in Fish Samples (ppm)

BW : Adult Body Weight $70 \mathrm{~kg}$, Children $14.5 \mathrm{~kg}$.

Rfd : Reference dose of Hg $0.0001 \mathrm{ppm}$

Daily Mercury Exposure Equation (PMH):

$$
\mathrm{Em}=(\mathrm{cm} \times \mathrm{CR}) / \mathrm{BW}
$$

Information:

Em : Daily Mercury Exposure (mg/kg /day)

$\mathrm{Cm} \quad$ : Mercury Concentration in Fish Samples (ppm)

BW : Adult Body Weight $70 \mathrm{~kg}$, Children $14.5 \mathrm{~kg}$.

CR : Average daily consumption of Adult fish = $0.227 \mathrm{~kg}$, children $=0.08 \mathrm{~kg}$

\section{Results and Discussion}

Mercury concentration in water

Mercury concentration during observation at each station can be seen in Figure 1. As shown in the figure above, the concentration of mercury had increased in February and decreased in April. The increase and decrease in concentration are caused by changes in the frequency of mining activities and hydrodynamic systems such as floods and currents.

In February, the concentration of mercury increased due to an increase in unlicensed mining activities which caused an increase in the volume of pollutants and receding waters resulting in concentrated mercury. Conversely, the decrease in mercury concentrations in April was due to a decrease in gold mining activities without permits due to law enforcement from law enforcement officers.

In this study, there were two water hydrodynamics systems such as floods and river currents that influenced the decrease in mercury concentration and made polluted water distributed to other regions. Melawi River has a length of $471 \mathrm{~km}$, experiences drastic tides, with upstream flow rates of $18,300 \mathrm{~m}^{3} / \mathrm{sec}$ and at the Down-stream of 24,452 $\mathrm{m}^{3} / \mathrm{sec}$, has an average annual temperature of around $23^{\circ} \mathrm{C}$, and has an average rainfall annual number of $4124 \mathrm{~mm}$. This is in accordance with the idea that the heavy metals in the waters will decrease due to the dynamics of the waters such as

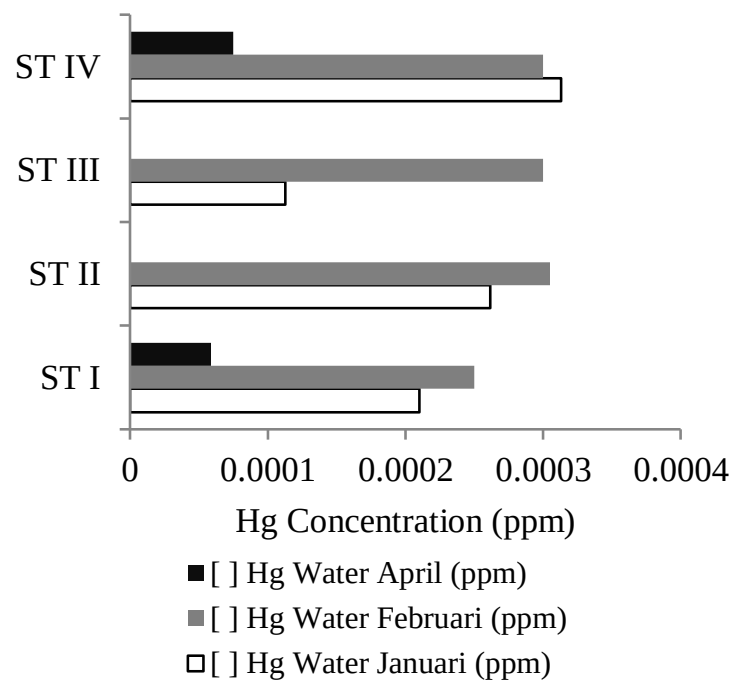

Figure 1. Mercury concentration in the water of observation stations

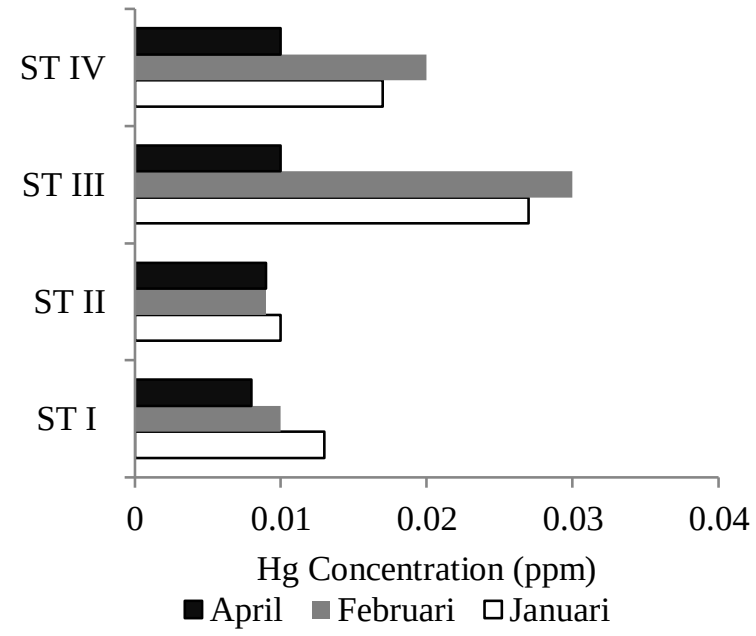

Figure 2. Mercury concentration in the water of observation stations

currents, waves, dilutions, reactions with organic and inorganic materials in the waters as well as the absorption by living things [7].

The highest concentration was found in observation station IV in the Lower Village of Tanjung Pauh Village. The high concentration is caused by the amalgamation process which is not carried out at the mining site but rather at the mining settlement.

\section{Mercury concentration in sediments}

Mercury concentration during observation at each station can be seen in Figure 2. The concentration of mercury in sediments was relatively unchanged between observation stations. The concentration of mercury in sediments in Tanjung Pauh Village was greater than in Lengkong Nya- 


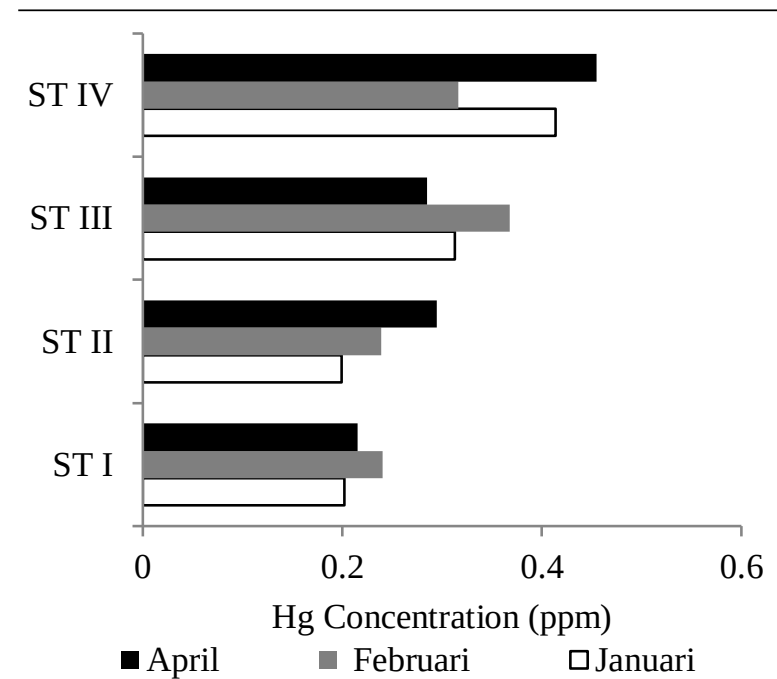

Figure 2. Mercury concentration in Lais fish

dom Village and Hilir Tanjung Pauh Village. As the month of observation progressed, there was a decrease and an increase in mercury concentrations from January to April. This decrease during the observation period was influenced by tidal currents and flooding which caused flushing of surface sediments so that the concentration of mercury tends to decrease. Meanwhile, the increase in mercury concentration was caused by the sedimentation rate.

\section{Mercury concentration in Lais (Kryptopterus) fish}

The concentration of mercury in Lais fish during the observation period at each station can be seen in Figure 3. The concentration of mercury in Lais fish has increased in line with the observation month. The more downstream of the river flow, the concentration of mercury in Lais fish is increasing. This relates to the quantity and time of exposure. The concentration of mercury in Lais (Kryptopterus) fish in the Lower Tanjung Pauh Village has exceeded the US EPA 823R-01-001 [8] quality standard of $0.3 \mathrm{ppm}$. This can have a negative impact on people who exposed to mercury.

One example of negative impacts caused by mercury is severe and chronic poisoning. Severe poisoning caused by mercury can be identified by observing several symptoms, for instance, the inflammation of pharyngitis, dysphagia, abdominal pain, nausea and vomiting, and nausea accompanied by blood and shock. If these initial symptoms are not treated immediately, the patient will subsequently experience swelling of the salivary glands, inflammation of the kidneys (nephritis) and inflammation of the liver (hepatitis). In chronic poisoning by mercury, there are two organs of the body that most often experience disorders, namely disorders of the digestive system and nervous system.

Another factor that influenced the concentration of mercury in Lais fish is its eating behavior as a predatory species. As a predatory species, Lais fish are most likely to be exposed to mercury from food sources that have been contaminated with mercury. Taftazani explained that the transformation process of mercury in the food chain system experiences multiplication (bioaccumulation) [9]. The concentration of mercury that enters and accumulates in the biota network continues to increase along with the increase in the strata or position of the biota in the food chain system known as biomagnification. So that biota such as large fish that have eaten smaller fish that have been contaminated with mercury, allegedly have a greater mercury content in the body and humans who occupy the top position of the food chain system will accumulate mercury in higher amounts [10].

\section{Bioaccumulation of mercury in Lais (Kryp- topterus) fish}

The potential for heavy metal accumulation is through bioconcentration in aquatic biota, especially benthic biota. Bioconcentration factors are usually through eating habits based on trophic levels (biomagnification). This can lead to increased metal build-up in the biota (bioaccumulation). The continuity of metal bioaccumulation in biota increases the toxicity and thus endangers the biota [11].

Bioconcentration is a function of biotransferring heavy metals from sediment to biota, which can cause biological effects. Several environmental factors play a role in determining the level of bioconcentration, namely $\mathrm{pH}$, organic matter, and dissolved organic carbon [6, 12, 13, 14]. Aquatic organisms accumulate mercury compounds in the form of $\mathrm{CH}_{3} \mathrm{Hg}^{+}$and $\mathrm{Hg}^{2+}$ at all levels of the food web [15]. Mercury bioaccumulation from various exposure pathways namely: water, feed and particulate matter [16].

The results of this accumulation increase the mercury content in the body tissues of the biota. The results showed that $80-90 \%$ of the mercury 
B Triswanto, MA Wibowo, P Ardiningsih, 2020/ A Study of Mercury Pollution in the Melawi Watershed

Table 2. Bioaccumulation factor (BCF)

\begin{tabular}{cccccc}
\hline Station & Month & $\begin{array}{c}\text { Hg Fish } \\
(\mathrm{mg} / \mathrm{kg})\end{array}$ & $\begin{array}{c}\text { Hg Water } \\
(\mathrm{mg} / \mathrm{kg})\end{array}$ & BCF & $\begin{array}{c}\text { BCF average/ } \\
\text { station }\end{array}$ \\
\hline I & January & 0.202 & 0.00021 & 961.9 & \\
& February & 0.240 & 0.00025 & 960 & 884.1 \\
& April & 0.2155 & 0.000295 & 730.5 & \\
II & January & 0.199 & 0.0002615 & 760.9 & \\
& February & 0.191 & 0.000305 & 626.2 & 837.8 \\
& April & 0.2945 & 0 & 1126.2 & \\
III & January & 0.3125 & 0.000113 & 2765.5 & \\
& February & 0.3675 & 0.0003 & 1225 & 2170.5 \\
& April & 0.285 & 0 & 2522.1 & \\
& January & 0.4135 & 0.000313 & 1321.1 & \\
& February & 0.3165 & 0.0003 & 1055 & 2814.3 \\
& April & 0.455 & 0.000075 & 6066.7 & \\
\hline
\end{tabular}

Table 2. Daily mercury exposure for adults

\begin{tabular}{cccccc}
\hline Station & Month & $\begin{array}{l}\text { Hg Fish } \\
(\mathrm{mg} / \mathrm{kg})\end{array}$ & CR/BW & PMH $\left(\mathrm{mg} / \mathrm{kg}^{-\mathrm{d}}\right)$ & $\begin{array}{c}\text { PMH average/station } \\
\left(\mathrm{mg} / \mathrm{kg}^{-\mathrm{d}}\right)\end{array}$ \\
\hline I & January & 0.2155 & 0.0032 & 0.000655 & \\
& February & 0.199 & 0.0032 & 0.000778 & 0.00071 \\
II & April & 0.191 & 0.0032 & 0.000699 & \\
& January & 0.2945 & 0.0032 & 0.000645 & \\
& February & 0.3125 & 0.0032 & 0.000619 & 0.00074 \\
III & April & 0.3675 & 0.0032 & 0.000955 & \\
& January & 0.285 & 0.0032 & 0.001013 & \\
& February & 0.4135 & 0.0032 & 0.001192 & 0.00104 \\
IV & April & 0.3165 & 0.0032 & 0.000924 & \\
& January & 0.455 & 0.0032 & 0.001341 & \\
& February & 0.2155 & 0.0032 & 0.001026 & 0.00316 \\
& April & 0.199 & 0.0032 & 0.007123 & \\
\hline
\end{tabular}

Table 3. Daily mercury exposure for children

\begin{tabular}{cccccc}
\hline Station & Month & $\begin{array}{c}\text { Hg Fish } \\
(\mathrm{mg} / \mathrm{kg})\end{array}$ & CR/BW & PMH $\left(\mathrm{mg} / \mathrm{kg}^{-\mathrm{d}}\right)$ & $\begin{array}{c}\text { PMH average/station } \\
\left(\mathrm{mg} / \mathrm{kg}^{-\mathrm{d}}\right)\end{array}$ \\
\hline I & January & 0.202 & 0.006 & 0.00111 & \\
& February & 0.240 & 0.006 & 0.00132 & 0.00121 \\
II & April & 0.2155 & 0.006 & 0.00119 & \\
& January & 0.199 & 0.006 & 0.00110 & 0.00126 \\
& February & 0.191 & 0.006 & 0.00105 & \\
III & April & 0.2945 & 0.006 & 0.00163 & \\
& January & 0.3125 & 0.006 & 0.00172 & \\
& February & 0.3675 & 0.006 & 0.00203 & \\
IV & April & 0.285 & 0.006 & 0.00157 & \\
& January & 0.4135 & 0.006 & 0.00228 & \\
& February & 0.3165 & 0.006 & 0.00175 & \\
& April & 0.455 & 0.006 & 0.00251 & Volume $10 \mid$ Number 3 | September $\mid 2020$
\end{tabular}


compounds contained in fish and shellfish were in the form of $\mathrm{CH}_{3} \mathrm{Hg}^{+}$[17]. Bioconcentration Factor (BCF) at each observation station can be seen in Table 2. The average bioconcentration of mercury in observation stations I and II is included in the accumulative category (BCF 100-1000) while in observation stations III and IV are classified as high accumulative (BCF > 1000).

\section{Daily mercury exposure (PMH)}

Mercury exposure in humans is about $95 \%$, because it is more easily absorbed by the body. Mercury will be distributed to all organs through the circulatory system. Mercury in the human body is commonly found in the kidneys, however the target organ for methyl mercury is the central nervous system. Methyl mercury in the body is relatively more stable. Mercury can penetrate the circulatory system, brain and placenta. Mercury exposure is critically occurring at doses of $10-40$ $\mu \mathrm{g} / \mathrm{kg}$ body weight. The critical effects caused by mercury include lymphocytic aneuploidy, discoloration of the front surface of the eye lens, insomnia, tremors and hyperexcitability.

The Joint Expert Committee on Food Additives [11] sets a weekly standard for consumption of fish and shellfish contaminated with mercury at $3.3 \mathrm{mg} / \mathrm{kg}$ body weight for adults. However, in 2006, taking into account the protection of infants and children who were deemed particularly sensitive to mercury, it set the safety standard of 1.6 $\mu \mathrm{g} / \mathrm{kg}$ body weight.

As shown in the Table 3 and 4 , it is known that daily mercury exposure for adults and children is still below the threshold. Based on the Table, it is determined that the weight of Lais (Kryptopterus) meat which is safe for consumption by adults in the upstream area of Lengkong Nyadom Village (ST I) is as much as $0.032 \mathrm{~kg} / \mathrm{day}$, while for children it is recommended to consume $0.007 \mathrm{~kg}$ of fish/day. The adult population of Lengkong Nyadom Village can consume $0.032 \mathrm{~kg} / \mathrm{day}$ of Lais meat while children $0.007 \mathrm{~kg} /$ day.

At Observation Station III (Tanjung Pauh Village), adults are advised to consume no more than $0.022 \mathrm{~kg} /$ day, while children should not exceed $0.006 \mathrm{~kg} /$ day. The downstream community of Tanjung Pauh village is advised to consume Lais Fish of $0.018 \mathrm{~kg} /$ day for adults and $0.004 \mathrm{~kg} /$ day. The average number of fish Lais (Kryptopterus) that are safe for consumption by the community around the Melawi watershed for adults is 0.026 $\mathrm{kg} /$ day, while children are $0.006 \mathrm{~kg} /$ day.

\section{Maximum limit daily consumption of Lais (Kryp- topterus)}

As shown in the table 5 and 6, daily mercury exposure for adults and children is still below the threshold. Based on Table 6, the weight of Lais (Kryptopterus) fish which is safe for consumption by adults in the upstream area of Lengkong Nyadom Village (ST I) is $0.032 \mathrm{~kg} /$ day, while for children it is recommended to consume $0.007 \mathrm{~kg} / \mathrm{day}$ of fish. The adult population of Lengkong Nyadom Village can consume $0.032 \mathrm{~kg} /$ day of Lais meat while children $0.007 \mathrm{~kg} /$ day.

At Observation Station III (Tanjung Pauh Village), for adults, it is recommended to consume no more than $0.022 \mathrm{~kg} /$ day while children no more than $0.006 \mathrm{~kg} /$ day. The downstream community of Tanjung Pauh village is advised to consume Lais Fish of $0.018 \mathrm{~kg} /$ day for adults and $0.004 \mathrm{~kg} /$ day. The average number of fish Lais (Kryptopterus) that are safe for consumption by the community around the Melawi watershed for adults is 0.026 $\mathrm{kg} / \mathrm{day}$, while children are $0.006 \mathrm{~kg} / \mathrm{day}$.

\section{Conclusion}

The results of study showed that the concentration of mercury in water, sediments, and Lais (Kryptopterus) fish from highest to lowest was $3.13 \times 10^{-4} \mathrm{ppm}, 0.02 \mathrm{ppm}$ (Tanjung Pauh Village), 0.395 ppm (Tanjung Pauh Village). Although Tanjung Pauh village is located a little far from the mining site, however the amalgamation was carried out by miners in this area.

The mercury measurement using Atomic Absorption Spectroscopy (AAS) showed that the average concentration of mercury found in the water was $1.80 \times 10^{-4} \mathrm{ppm}$, sediments $1.33 \times 10^{-2} \mathrm{ppm}$, and Lais fish 0.291 ppm. Meanwhile, the average bioconcentration factor (BCF) of mercury in Lais fish was $1.677 \mathrm{ppm}$, which is categorized as heavy accumulative. Therefore, the maximum daily consumption of Lais fish that were safe for the community consumption at the Melawi watershed was $0,026 \mathrm{~kg} / \mathrm{day}$ for adults and $0.006 \mathrm{~kg} /$ day for the children.

\section{Acknowledgement}

The author's sincere appreciation is given to the Melawi Regency Government who has given 
a study permit to the author so this research can be done.

\section{References}

1. Badan Pusat Statistik (2012) Melawi dalam angka, BPS, Melawi

2. Schwindt AR, Fournie JW, Landers DH et al. (2008) Mercury concentration in salmonids from western US National Parks and relationships with age and Macrophage Aggregates. Environment Science Technology 42 (4): 1365-1370. doi: 10.1021/es8002603.

3. Darmono (2001) Lingkungan hidup dan pencemaran; hubungannya dengan toksikologi senyawa logam. Indonesian University Press, Jakarta.

4. Effendi H (2003) Telaah kualitas air. Kanisius, Yogyakarta.

5. Anonymous (2001) Preventive measures against environment mercury pollution and its health effects. In Japan Public Health Association 112.

6. LaGrega, MD, Phillip L. Buckingham, Jeffry C (2001) Evans and environmental resources management. Hazardous Waste Management. 2nd Edition. Waveland Press, New York.

7. US EPA (2000) Guidance for Assessing Chemical Contaminant Data for Use in Fish Advisories: Risk Assessment and Fish Consumption Limits, Office of Water, EPA 823-B-00-008. 7. EPA, New York.

8. US EPA (2009) Water quality for the protection of human health: Methylmercury. Office of Water, EPA 823- R-01001 8. EPA, New York.

9. Taftazani, A (2004) Proceedings of PPI - PDIPTN Pustek Akselerator dan proses bahan. PTAPB-BATAN, Yogyakarta.
10. McIntyre JK, Beauchamp DA (2007) Age and trophic position dominate bioaccumulation of mercury and organochlorines in the food web of Lake Washington. Science of The Total Environment 372 (23): 571-584. doi: 10.1016/j.scitotenv.2006.10.035.

11. Badan Standardisasi Nasional (2009) SNI 7387:2009, Batas maksimum cemaran logam berat dalam pangan. BSN, Jakarta.

12. Riani E (2012) Perubahan iklim dan kehidupan biota akuatik (Bioakumulasi bahan berbahaya dan beracun dan reproduksi). IPB Press, Bogor.

13. Akkanen J, Kukkonen JVK (2003) Biotransformation and bioconcentration of pyrene in Daphnia Magna. Aquatic Toxicology 64 (1): 53-61. doi: 10.1016/S0166445X(03)00023-7.

14. Kojadinovic J, Potier M, Le Corre M et al. (2006) Mercury content in commercial pelagic fish and its risk assessment in the Western Indian. Science of The Total Environment 366 (2-3): 688-700. doi: 10.1016/j.scitotenv.2006.02.006.

15. Suprapti NH (2008) Kandungan chromium pada perairan, sedimen dan kerang darah (Anadara granosa) di wilayah pantai sekitar muara Sayung desa Morosari kabupaten Demak, Jawa Tengah. Bioma 10 (2): 36 - 40.

16. Luo W, Wang T, Jiao W et al. (2012) Mercury in coastal watersheds along the chinese northern bohai and yellow seas. Journal of Hazardous Materials 215-216: 199-207. doi: 10.1016/j.jhazmat.2012.02.052.

17. Selid PD, Xu H, Collins EM et al. (2009) Sensing mercury for biomedical and environmental monitoring: Review. Sensor 9 (7): 5446-5459. doi: 10.3390/s90705446. 
B Triswanto, MA Wibowo, P Ardiningsih, 2020/ A Study of Mercury Pollution in the Melawi Watershed

This page is intentionally left blank 